\title{
Oestrogens and Milk Fever - is there a Link?
}

\author{
By E. Pyörälä, S. Pyörälä, M. Mero and H. Adlercreutz
}

Ambulatory Clinic, College of Veterinary Medicine, Hautjärvi, and Department of Clinical Veterinary Medicine, College of Veterinary Medicine, Helsinki, and Department of Clinical Chemistry, University of Helsinki, Meilahti Hospital, Helsinki, Finland.

\begin{abstract}
Pyörälä, E., S. Pyörälä, M. Mero and H. Adlercreutz: Oestrogens and milk fever - is there a link? Acta vet. scand. 1992, 33, 335-339. - The trial involved 42 cows with clinical milk fever. Thirteen heifers and 32 cows without symptoms served as controls. Calcium, oestradiol and oestrone concentrations in serum were determined in blood samples taken within $6 \mathrm{~h}$ before or after parturition. Serum oestradiol and serum calcium concentrations correlated negatively. There was no association between oestrone and calcium concentrations. The results suggest that oestradiol plays a role in the aetiology of milk fever.
\end{abstract}

serum oestrone; serum oestradiol; serum calcium; puerperal paresis.

\section{Introduction}

Disturbances of calcium (Ca) homeostasis associated with parturition increase with age. Onset of lactation causes copious loss of humoral calcium. Although parturient paresis is rare in heifers, they may go through a phase of hypocalcaemia. However, the intestines and bones of young animals adapt quickly to compensate for Ca loss. Capacity for adaptation diminishes with age. Intestinal Ca absorption declines, and capacity to use $\mathrm{Ca}$ resorbed from bones also diminishes. The homeostatic mechanism can be activated by a pre-partum low-calcium diet, which facilitates intestinal absorption of Ca post-partum and makes resorption from the bones more effective.

There have been suggestions that a high calving oestrogen level is associated with occurrence of milk fever. It has been suggested that a high calving oestrogen level diminishes $\mathrm{Ca}$ resorption from bone and keeps plasma Ca concentrations low (Hollis et al. 1981). However, conflicting results have been reported (Comline et al. 1974). In most studies oestrogen concentrations have been monitored in small groups of cows prior to and during calving.

This study was performed as a field trial. The purpose was to investigate whether or not there was an association between serum oestrogen concentration and puerperal paresis, using blood samples taken close to the calving. Further monitoring of the animals was not possible.

\section{Materials and methods}

In the area covered by the Ambulatory Clinic of the College of Veterinary Medicine, Hautjärvi, 42 cows suffering from milk fever were examined during routine calls. Thirteen heifers and 32 cows without symptoms of parturient paresis were selected from the same farms as controls. The criterion for inclusion of test and control animals was that the animal had calved or would calve within $6 \mathrm{~h}$ of the time of examination. In the latter case, the time of calving was checked afterwards.

The animals were examined clinically, with 
emphasis on appetite, disturbances of rumen activity and defaecation, and other symptoms suggestive of hypocalcaemia.

Eleven cows in the control group gave birth to their second calf. The other 22 had calved 3-7 times (median 3.5 times). In the group of cows with parturient paresis, 1 cow had calved twice, the others 3-9 times (median 6 times).

A blood sample was taken from the jugular vein in connection with clinical examination. The blood was allowed to clot and the serum was subsequently separated. Following determination of total serum calcium concentration, the rest of the serum was frozen and kept at $-18^{\circ} \mathrm{C}$ for subsequent determination of oestradiol $17-\beta$ and oestrone concentrations. Serum oestrone and oestradiol levels were determined by radioimmunoassay after extraction and chromatography (Goldin et al. 1982). For extraction, 5 volumes of $20 \%$ ethyl acetate in petroleum ether were used. Separation was carried out by freezing in a single step. After evaporation the extract was added to a Sephadex column, using a Pasteur

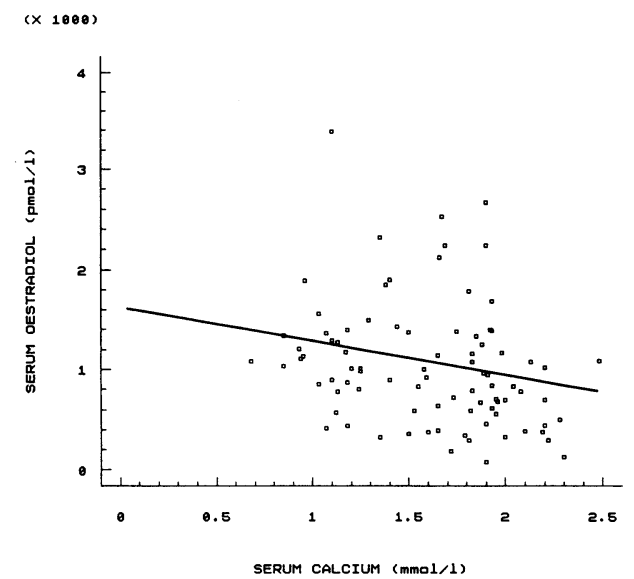

pipette, in $20.1 \mathrm{ml}$ portions of $9 \%$ methanol in toluene. The column was eluted with the same solvent. The first fraction $(1.1 \mathrm{ml})$ was discarded, the next $(1.3 \mathrm{ml})$ contained oestrone. This was followed by a $0.4 \mathrm{ml}$ fraction (discarded). Oestradiol was then eluted in the next $2.8 \mathrm{ml}$ of the same solvent. Radioimmunoassay was carried out using specific antisera and separation with dextran-coated charcoal in the usual way. For each batch of analyses, high and low control samples were included. The practical detection limit is 10-20 pmol/l. Variation between results from duplicate assays of a control serum pool was $5.1 \%$ for oestrone and $3.9 \%$ for oestradiol. Variation between assays calculated from mean values of such duplicates over 3 years, was $2.0 \%$ for oestrone and $1.4 \%$ for oestradiol.

Correlation coefficients were calculated, one-way analysis of variance was undertaken and Student's unpaired t-test was applied. All calculations were carried out using logarithmically transformed values since the data were skewed.

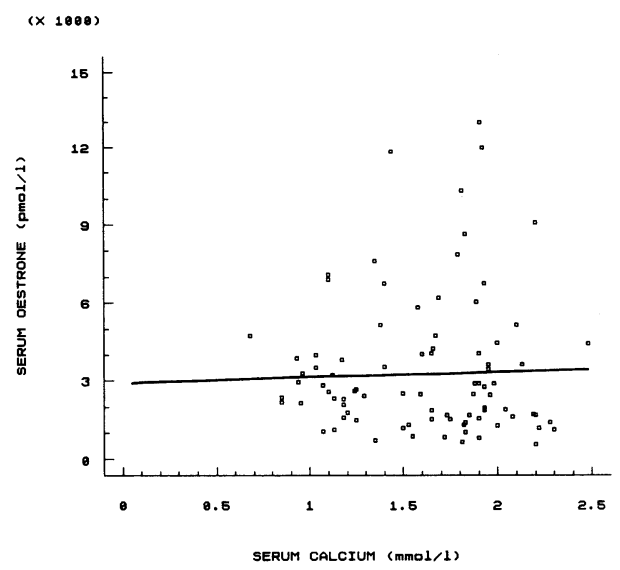

Figure 1. Relationships between serum oestradiol (left panel) and serum oestrone (right panel) levels and serum calcium values. Fitted regression lines are also shown. 


\section{Results}

Serum oestradiol concentrations were negatively correlated $(\mathrm{p}<0.05)$ with serum $\mathrm{Ca}$ concentration. Taking a Ca concentration of $1.7 \mathrm{mmol} / \mathrm{l}$ as the threshold for hypocalcaemia, the difference in serum oestradiol levels between hypocalcaemic and other animals was significant $(\mathrm{p}<0.05)$. No association was found between oestrone and calcium levels. Scatter plots of individual plasma calcium values in relation to oestradiol and oestrone levels are shown in Fig. 1.

As expected, serum calcium concentrations in cows with clinical milk fever were significantly lower than those in cows of the same age with no symptoms (geometric mean 1.25 and $1.77 \mathrm{mmol} / \mathrm{l}$, respectively). Serum oestrone levels in these groups did not differ. The mean serum oestradiol level was lower in the no-milk-fever group (Table 1.). Geometric mean concentrations of oestradiol in the first and second calvers were $652 \mathrm{pmol} / \mathrm{l}$ and that in older cows $952 \mathrm{pmol} / \mathrm{l}$ but the increase with age was not statistically significant. No association was found between serum oestrone levels and age.

\section{Discussion}

Placental oestrogen production increases approximately 2 weeks before calving. There are large differences between individuals.
Concentrations are significantly higher in uterine veins than in the peripheral circulation (Comline et al. 1974). Hepatic fat accumulation causing liver dysfunction can reduce elimination of oestrogens and could explain why oestrogen concentrations are high in some animals (Lunaas 1981).

In our study, high serum oestradiol 17- $ß$ concentrations close to calving were significantly associated with low calcium levels. The threshold for hypocalcaemia was taken to be 1.7 $\mathrm{mmol} / \mathrm{l}$ rather than the $2.0 \mathrm{mmol} / \mathrm{l}$ commonly taken in other studies. By choosing a lower cut-off point we hoped to exclude cases of physiological $\mathrm{Ca}$ concentration decrease caused by onset of lactation. Taking clinical symptoms of milk fever as criteria for hypocalcaemia is risky since assessment of clinical symptoms depends on individuals. Moreover, not all animals react similarly to the fall in Ca concentration, which makes assessment of symptoms difficult.

Serum oestrogen concentrations did not differ between cows with clinical milk fever and those without. Serum calcium concentrations differed significantly. Total serum Ca level does not reliably characterize the availability of calcium to an organism. More than half of all $\mathrm{Ca}$ is protein-bound, mostly to albumin. Ionized calcium participates actively in body functions. Consequently, total Ca levels and

Table 1. Means and standard errors of calcium, oestradiol and oestrone levels in serum of cows in different age groups with or without clinical signs of milk fever.

\begin{tabular}{|c|c|c|c|c|}
\hline $\begin{array}{l}\text { Age } \\
\text { (No. of } \\
\text { calvings) }\end{array}$ & $\begin{array}{l}\text { No. of } \\
\text { cows }\end{array}$ & $\frac{\begin{array}{c}\text { Calcium } \\
\mathrm{mmol} / \mathrm{l}\end{array}}{\text { geom. mean } \pm \text { s.e. }}$ & $\begin{array}{c}\begin{array}{c}\text { Oestradiol } \\
\mathrm{pmol} / \mathrm{l}\end{array} \\
\text { geom. mean } \pm \text { s.e. }\end{array}$ & $\begin{array}{c}\begin{array}{c}\text { Oestrone } \\
\text { pmol/ } /\end{array} \\
\text { geom. mean } \pm \text { s.e. }\end{array}$ \\
\hline First & 13 & $2.03 \pm 0.06$ & $659 \pm 95$ & $2748 \pm 1061$ \\
\hline Second & 11 & $1.91 \pm 0.07$ & $644 \pm 266$ & $2476 \pm 604$ \\
\hline \multicolumn{5}{|c|}{ Third and more: } \\
\hline No milk fever & 22 & $1.77 \pm 0.06$ & $877 \pm 162$ & $2722 \pm 464$ \\
\hline With -"- & 41 & $1.25 \pm 0.05$ & $995 \pm 76$ & $2704 \pm 426$ \\
\hline
\end{tabular}


clinical pictures do not necessarily agree (Lincoln \& Lane 1990). Ionized Ca levels were not determined in our study.

In studies of osteoporosis in postmenopausal women it has been found that reduction in oestrogen level changes the sensitivity of bone to parathyroid hormone (PTH), increasing break-down of bone (Johnson et al. 1983). Most cows with symptoms of parturient paresis have elevated serum PTH and 1,25 (OH)2D3 (an active derivative of vitamin D3) levels. During milk fever, the actions of these hormones are inhibited by small numbers of receptors in the target organs, namely the intestines, bone and kidney. The numbers of receptors diminish with age. Older animals also have fewer osteoclasts in their bones to react to PTH stimulation. Calcium resorption is therefore ineffective in situations of acute need (Reinhardt et al. 1979).

Results in the literature relating to a possible role of oestrogens in the initiation of milk fever are contradictory. The main hypothesis, based on human data, is that high oestrogen levels predipose to milk fever. Our results relating to oestradiol levels are in conformity with this. Conflicting results have been obtained by Canadian investigators who followed oestrogen changes in cows from as early as 30 days pre-partum. They detected the highest oestrogen levels in cows that did not develop paresis. Hydroxyproline levels in these cows were high 2 days before calving, reflecting bone resorption. In cows with milk fever, the rise of hydroxyproline did not take place until 2 days post-partum (Hollis et al. 1981). Other investigators have found high hydroxyproline levels on the day of calving in healthy cows (Nurmio \& Rajakoski 1973). In women, oestradiol has been found to be a more potent inhibitor of bone resorption than oestrone (Johnson et al. 1983). At the end of bovine pregnancy, oestrone is the most abundant oestrogen. The role of oestrone in calcium homeostasis is probably minor. The study results reported here do not indicate a connection between onset of milk fever and oestrone levels, which is in conformity with results of a Swedish group (Edqvist et al. 1974). On the other hand, a low oestrone level has been claimed by Sasser et al. (1979) to predispose to hypocalcaemia.

The negative correlation between serum oestradiol and serum calcium levels found in this study nevertheless suggests a role of oestrogens in the aetiology of hypocalcaemia. It is known that a rise in oestrogen level is associated with diminished appetite when calving approaches (Lunaas 1982). Intestinal absorption is reduced and calcium homeostasis is disturbed. The aetiology of hypocalcaemia and the possible role of oestrogens need further investigation.

\section{References}

Comline RS, Hall LW, Lavelle RB, Nathanielsz PW, Silver $M$ : Parturition in the cow: Endocrine changes in animals with chronically implanted catheters in the foetal and maternal circulations. J. Endocr. 1974, 63, 451-472.

Edqvist LE, Ekman L, Gustafsson B, Lindell JO: Estrone and progesterone plasma levels of normal cows and cows with parturient paresis. Acta vet. scand. 1974, 15, 587-596.

Eley DS, Thatcher WW, Head HH, Collier RJ, Wil$\operatorname{cox} C J$ : Periparturient endocrine changes of conceptus and maternal units in Jersey cows bred for milk yield. J. Dairy Sci. 1981, 64, 2, 296311.

Goldin BR, Adlercreutz H, Gorbach SL, Warram $J H$, Dwyer JT, Swenson L, Woods MN: Estrogen excretion patterns and plasma levels in vegetarian and omnivorous women. New Engl. J. Med. 1982, 307, 1542-1547.

Hollis BW, Draper HH, Burton JH, Etches RJ: A hormonal assessment of bovine parturient paresis: Evidence for a role of oestrogen. J. Endocr. 1981, 88, 161-171. 
Johnston CC, Hui SL, Longcope C: Oestrogen and calcium in management of osteoporosis. In: Dixon A., et al. (eds.): Osteoporosis, a Multidisciplinary Problem. Royal Society of Medicine Int. Congress and Symposium Series No 55. London. Academic Press. 1983, pp. 223-229.

Lincoln SD, Lane VM: Serum ionized calcium associated with calcium abnormalities. J. Amer. vet. med. Ass. 1990, 197, 1471-1474.

Lunaas T: Oestrogener og hypokalsemi ved kalvning. (Oestrogens and hypocalcemiae at calving). Norsk VetTidsskr. 1981, 93, 704-705.

Nurmio P, Rajakoski E: Hydroxyproline excretion in bovine puerperal paresis with special reference to bone resorption. J. vet. Med. A. 1973, 20, 609-613.

Reinhardt TA, Horst RL, Goff JP: Calcium, phosphorus and magnesium homeostasis in ruminants. In: Herdt, T.H. (ed): The Veterinary Clinics of North America, Food Animal Practice. Philadelphia. W.B.Saunders Company: 1988, pp. 331-350.
Sasser $R G$, Falk $D E$, Ross $R H$ : Estrogen in plasma of parturient paresis and normal cows. J. Dairy Sci. 1979, 62, 551-556.

\begin{abstract}
Sammanfattning
Östrogen och puerperal pares - finns det ett samband?

Undersökningen bestod av 42 kor med klinisk pares. Tretton förstakalvare och 32 kor utan kliniska symptom utgjorde kontrollgruppen. Koncentrationen av kalcium, östradiol och östron i serum uppmättes inom $6 \mathrm{t}$ före till $6 \mathrm{t}$ efter kalvningen. Inget samband mellan koncentrationerna av östron och kalcium kunde påvisas, däremot förelåg en negativ korrelation mellan serum östradiol och serum kalcium.

Resultaten tyder på att östradiol kan spela en roll i den puerperala paresens etiologi.
\end{abstract}

(Received April 9, 1992; accepted July 2, 1992).

Reprints may be requested from: Satu Pyörälä, Ambulatory Clinic, College of Veterinary Medicine, SF-04840 Hautjärvi, Finland. 